\begin{tabular}{rr} 
çağdaş & Yaratıcı Drama Dergisi 2017, 12(2), 77-86 \\
drama & www.yader.org \\
\hline
\end{tabular}

\title{
Resim İş Öğretmenliği Programında Müze Eğitimi ve Uygulamaları Dersinin İşlevi
}

\author{
Nami Eren Beştepe ${ }^{1}$
}

\begin{tabular}{|c|c|}
\hline Makale Bilgisi & $\ddot{\mathbf{O} z}$ \\
\hline DOI: $10.21612 /$ yader.2017.014 & $\begin{array}{l}\text { Son ylllarda kültür, sanat, bilim ve teknolojideki ilerlemelerin müzeleri de } \\
\text { etkilediği görüllür. Müzelerin tüm islevlerinin yant stra eğitim islevinin son yıllarda }\end{array}$ \\
\hline Makale Geçmişi & $\begin{array}{l}\text { daha da öne çıtı̆̆g açıktır. Bireyin değişen eğitim gereksinimleri yeni yöntem, } \\
\text { vaklasım ve ögrenme ortamlart aravıların hızlandırmıstır. Günümüzde müzeler }\end{array}$ \\
\hline Geliş tarihi & koleksiyonlarıly birlikte önemli bir ögrenme ortamı olarak kabul edilir. Müze \\
\hline 01.12 .2017 & 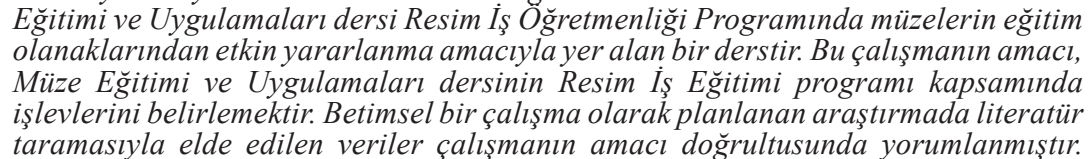 \\
\hline Anahtar Sözcükler & Çalışmada, Müze Eğitimi ve Uygulamalart dersinin işlevleri; yüzyllar boyunca \\
\hline Müze eğitimi & sunan müzelerden etkili yararlanma yollarını göstermek; müzelere kaşı ilgi \\
\hline $\begin{array}{l}\text { Müze eğitimi ve uygulamalarl } \\
\text { dersi }\end{array}$ & $\begin{array}{l}\text { uyandırarak bir müze bilinci oluşturmak; sanata ilişkin konuların müze ve } \\
\text { galerilerle işbirliği halinde işlenmesini desteklemek ve bunun yollarını göstermek; } \\
\text { sanat eğitimi bağlamında izleyici ile orijinal sanat eserlerinin bir araya gelebildiği } \\
\text { ve izleyicinin doğrudan eserle bağ kurabildiği müze, galeri ve sergilerin bu açıdan } \\
\text { önemini göstermek; Müze Eğitimi ve Uygulamaları dersi kapsamında yaplacak } \\
\text { müze ve galeri ziyaretleriyle, kültür ve sanat mekanlarına karşı ilgi uyandırmak, } \\
\text { allşkanlı geliştirmek ve varsa çekingenlikleri gidermek olarak belirlenmiştir. }\end{array}$ \\
\hline
\end{tabular}

\section{The Role and Purpose of Museum Practices and Education Course in Arts Teacher Training Program}

\begin{tabular}{lr} 
Article Info \\
\hline DOI: $10.21612 /$ yader.2017.014 \\
\hline Article History & \\
Received & 03.11 .2017 \\
Accepted & 01.12 .2017
\end{tabular}

Keywords

Museum Education

Museum practices and education course

\begin{abstract}
Recent developments in culture, arts, science and technology is proactively affecting museums. Together with all other services provided the educational functions of museums have become all the more obvious. As well, changing skillset and educational needs of persons has accelerated the search for alternative approaches, methods and educational settings. Currently, museums are deemed to essential educational environments together with their collections. Museum Practices and Education Course is designed to actively utilise the educational faculties of museums in Arts Teacher Training Programs. The purpose of this study is to define the goals and objectives of Museum Practices and Education Course within the Arts Teacher Training Programs. Designed as descriptive research, the results of literature review are collated on par with the aims of the study. In sum, the aims and objectives of the Museum Practices and Education Course are defined as: enabling persons in ways of actively utilising museums, which serve as a hub for the sum of humanities cultural, artistic, scientific and technological creations, to the fullest; raising awareness about and rousing interest in museums; supporting the cultivation of artistic matters and events in collaboration with galleries and museums and showing ways of doing so; in the context of arts education, pointing out the importance of museums, galleries and exhibitions where genuine art and viewers meet and persons can directly relate to creations; raising interest in galleries and museums by organising tours through the Museum Practices and Education Course, develop positive habits and mitigate related reservations.
\end{abstract}




\section{Giriş}

Müzeciliğin temeli olarak koleksiyonlar bilinir. İnsan yüzyıllar boyunca merak ettiği, ilgi duyduğu nesneleri toplamış ve biriktirmiştir. Günümüzde de pek çok kişi çeşitli nesnelerle koleksiyonlar oluştururlar. Bir araya getirdikleri nesneleri incelemenin, onların özelliklerini öğrenmenin ve bu koleksiyonlarını başka kimselere izletmenin, onlar hakkında bilgi vermenin koleksiyonerlere zevk verdiği söylenebilir. Kuşkusuz koleksiyon oluşturmak bir ilgi ve merak işidir. M.Ö. 12. yüzyılda Elam Kralı Şutruk-Nahhunde'nin Mezopotamya'nın çeşitli sanat özelliklerini yansıtan taş eserlerini toplayarak, Suza'da bir araya getirmesi ilk koleksiyonlardan biri olarak kabul edilir (Erkanal, 1983). Sanat eserlerini toplama, bir araya getirme çabaları çağlar boyu birçok kişi tarafindan da sürdürülmüştür. Erkanal'a (1983) göre,16. yüzyılla birlikte, koleksiyoncular çeşitli sanat dallarının yanında artık arkeoloji, tarih, fen etnografya ve tabiat tarihi gibi konularla da ilgilenmeye başlamışlardır. 17. ve 18. yüzyıllarda Orta Avrupa ülkelerinde başlayan koleksiyon yapma merakı ve tutkusu giderek bütün öteki ülkelere yayılmıştır. Batur'a (1983) göre, ne tür dürtü ile toplanmış, biriktirilmiş olursa olsun, sanat ve bilim eserlerinden oluşan bu tür koleksiyonlar ilk müze örnekleri olarak görülebilirler.

İngiltere'de ilk büyük müzenin 1683'de, British Museum'un 1759'da; Amerika'da 1773'de; Fransa'da 1793'de kurulmuş olduğu (Özsezgin, 1973; Beştepe, 1995; 24) düşünülürse, günümüzde anlaşıldığı şekliyle müze anlayışının yaklaşık üç yüz, üç yüz elli yıla yakın bir geçmişe sahip olduğu söylenebilir. İlk müze örneklerinden günümüze gelindiğinde müzeciliğin gelişerek çok değiştiği görülür.

Son yüz yılda yaşanan hemen her alanda hızlı gelişme ve değişimlerin toplumları da etkilediği görülür. Bu gelişmelerden eğitim dizgelerinin de etkilendiği izlenir. Değişen ve artan eğitim taleplerini karşılamak için ülkeler eğitim dizgelerini gözden geçirmekte ve farklı çözüm yolları ortaya koymaya çalışmaktadırlar.

Değişimden etkilenen bir kurum da müzelerdir. Artık müzeler sadece nesneleri toplayan, koruyan ve onları sergileyen kurumlar değil, aynı zamanda koleksiyonları kapsamında eğitim hizmeti veren kurumlar olarak da görülürler. Günümüzde müzelerin birer kültür ve sanat merkezi ve eğitim ve öğrenme ortamı oldukları tartışma götürmez bir gerçektir. Müzelerin insanlığın çağlar boyu ürettiği nesneleri toplaması, onları koruması, incelemesi ve sergilemesi önemli işlevlerdir. Çağlar boyu insanlığın ürettiği nesneleri yine insanlığın gelişimine sunulması müzelere bir işlev daha yükler; eğitim işlevi. Onur’a (2012) göre, “insanın gelişimine katkıda bulunmak müzenin en önemli işlevi olmuştur."

Müzelerden eğitim amaçlı yararlanmanın 20.yüzyılla birlikte daha da arttığı görülür. Müzeler bir eğitim ve öğrenme ortamı olarak değerlendirilirken, müzelerden eğitim amaçlı yararlanma yollarını geliştirmek için de farklı çalışmalar yapılmaktadır. Müzelerin eğitim işlevinin öne çıkması müze eğitimi alanını ortaya çıkarmıştır. Disiplinlerarası bir çalışma alanı olarak düşünülebilen müze eğitiminin, genel olarak müzelerden eğitim ve öğretim amaçlı yararlanma yolları üzerine çalışan bir alan olduğu söylenebilir.

Öğretmen Yetiştirme Programlarından Resim İş Öğretmenliği Programına 1998 yılında Müze Eğitimi ve Uygulamaları dersi konmuştur. Müze Eğitimi ve Uygulamaları dersi hem müze eğitimi çalışmalarını hem de programda yer alan kimi derslerin sanat eserleriyle ilgili çalışmalarını desteklemek açısından bir görev üstlenmiştir. Dersin, bu görevi yerine getirirken zaman içinde bazı 
işlevleri öne çıkmıştır. Bu çalışmada Müze Eğitimi ve Uygulamaları dersinin işlevleri belirlenmeye çalışılmıştır. Resim İş Öğretmenliği Programında önemli bir yeri olan sergilerin değerlendirildiği galeri eğitimi de Müze Eğitimi ve Uygulamaları dersi kapsamında ele alınmıştır.

Çalışmanın amacı, Resim İş Öğretmenliği Programı'nda yer alan Müze Eğitimi ve Uygulamaları dersinin zaman içinde öne çıkan işlevlerini belirlemektir. Bu kapsamda betimsel bir çalışma olarak planlanan araştırmada literatür taramasından elde edilen veriler çalışmanın amacı doğrultusunda yorumlanmıştır.

\section{Müze}

Uluslararası Müzeler Konseyi müzeyi, "kültürel değere sahip bir bütünü, çeşitli araçlarla korumak, incelemek, değerlendirmek ve özellikle halkın estetik beğenisinin yükselmesi ve eğitimi için sergilemek amacıyla kamu yararına yönetilen sürekli bir kurumdur” (Riviere, 1962: 23-24) şeklinde tanımlamaktadır. Kültürel değere sahip bir bütünden söz ediliyorsa ve kültür de insanın ürettiği her şey olarak belirlenirse, o zaman müze yüzyıllardan bu yana insanın ürettikleri üzerine yapılanmaktadır. Müzeler, bugün de dahil olmak üzere insanlığın ürettikleriyle yine insanları buluşturan kurumlardır. İnsanın ürettiklerini (belli bir bütünlük çerçevesinde) toplayan, koruyan, bunları araştıran ve sergileyen müzeler, insanlığın gelişimini de ortaya koymaktadırlar. İnsanlar, içinde bulundukları çağın da farkında olarak, sergilenen nesnelerle, dünden bugüne insanlığın gelişimiyle ilgili bilgi ve deneyim edinirler.

Atagök’e $(2006,59)$ göre, “amaç topluma ve onun gelişimine hizmetse, çizginin bir ucunda birey ve toplum, diğer ucunda ise insana ve yaşadığı çevreye tanıklık eden malzemelerin bulunması, müzeleri bu iki grup arasında ilişkiyi kuran, iletişimi sağlayan kurumlar olarak önemli bir konuma getirmiştir. Müze, toplayan, araştıran, belgeleyen, bilgi toplayan, koruyan, depolayan, sergileyen ve eğitim veren bir kurum olarak insanın geçmişten günümüze olan tüm gelişimini nesnelerle topluma iletir...".

Müzeler şu ana kadar belirtilen işlevlerini ICOM'un tanımında da belirtildiği gibi kamu yararına gerçekleştirmeye çalışmaktadırlar. Müzelerin kamu yararı yönetilmeleri, günümüzde kendi içinde bir tartışma barındırsa da, herkese açık olmayı ve kar gütmemeyi gerektiriyor. Öne çıkan eğitim işleviyle birlikte müzeler, ziyaretçi yani birey merkezli olup, herkesin yararlanabileceği kurumlar olmalı, olabilmelidir.

Yukarıda belirtilen tanımda geçen "kültürel değere sahip bir bütün" ifadesi temel alınırsa, kültürün de insanın ürettiği her şey olduğu düşünülürse, müzelerin insanlarla, yine insanların geçmişten günümüze ürettikleri nesnelerle bir araya geldikleri, buluştukları ya da karşılaştıkları yerlerdir. Müzelerin (koleksiyonların) ziyarete açılması, insanın ürettikleriyle yani nesnelerle ziyaretçilerin buluşması başlangıçta önemli bir adım olsa da günümüzde bu buluşma, karşılaşma kendi başına yeterli değildir.

\section{Müze Eğitimi}

Gelişen müzecilik anlayışı ile birlikte, müzelerde sergilenen nesneler ile ziyaretçilerin karşılaşmalarının tek başına yeterli olmadığı görüşü öne çıkar. Çünkü müzeler, yüzyıllarca insanın ürettiği, özel öneme sahip, çeşitli alanlarla ilişkili pek çok nesneyi barındırmaktadır. Bu nesnelerin insanın geçmişiyle geleceği arasında bir köprü oluşturabileceği gibi içinde bulunduğu çağı daha 
iyi anlamasına, anlamlandırmasına da katkı sağlayabilecek nesnelerdir. Belki onlarca sayfada yazılanlarla zor anlatılabilen bir konu, müzede ilgili nesne ya da nesnelerle çok hızlı ve daha kalıcı bir biçimde anlatılabilir, kavratılabilir. Bu nedenle, müzeler önemli bir bilgi kaynağı olarak, bir eğitim ve öğrenme ortamı konumuna gelmişlerdir.

Müzelerde nesnelerin sadece sergilenmesi ve ziyaretçilerin onları izlemelerinin sağlanması, müzelerin potansiyelini yeterince kullanmamak, onlardan yararlanmamak anlamına gelir. Dolayısıyla, ne yapılmalı ki, müzelerde sergilenen koleksiyonlardan, nesnelerden daha fazla yararlanılabilinsin? $\mathrm{Bu}$ sorunun uzun yıllardır sorulduğu ve farklı biçimlerde yanıtlar bulunduğu ve bu yanıtların giderek arttığı da söylenebilir. Günümüzde ziyaretçilerin, müzelerin potansiyelinden, müzelerin öğrenme olanaklarından, çeşitli programlar, etkinlikler, yöntem ve tekniklerle yararlanmaları sağlanmaya çalışılmaktadır. Akmehmet'e $(2012,196)$ göre, "günümüzde müzelerde eğitim çalışmalarının temel görevi 'müzenin eğitim potansiyelini en üst düzeye çıkarmak ve farklı izleyici gruplarına ulaşmaktır.' Tran’a (Akt. Onur, 2012; 169) göre, “müzeler öğrenme ve öğretme çevreleridir; bu çevrelerin özgür seçime ve değerlendirme yapmaya dayanan doğası öğrenmeyi desteklemekte ve geliştirmektedir. İnsanlar ve özellikle çocuklar doğuştan öğrenme isteğine sahiptirler, müze gibi informal çevreleri belirleyen özellikler öğrenmeye yönelik içsel güdüyü beslerler”.

Akmehmet'e $(2012,196)$ göre, “müzelerde eğitim çalışmaları 20.yy.'1n ikinci yarısından sonra önem kazanmaya başlamıştır. 1950'lere kadar daha çok okul gruplarına yönelik etkinlikler gerçekleştirilirken, 1970'lerden sonra yetişkinliklere yönelik çalışmalar da yaygınlaşmaya başlamıştır. Özellikle “1990’lardan sonra öğretmen, öğrenci ve yetişkinlerin yanında aileler ve engelliler gibi farklı izleyicilere yönelik eğitim yöntemleri hakkındaki araştırmalar ile müzelerdeki eğitimin kapsamı genişlemiştiı”"

Müzelerin eğitim işlevinin öne çıkmasıyla birlikte yukarıda da değinildiği gibi müze eğitimi alanı ortaya çıkar. Paykoç ve Baykal'a $(2000,103)$ göre, "Eğitim ve öğrenmede insan ve toplum ile ilgili kaynakların ve alanların yaşamın bir parçası olarak kullanılmasına öncelik verilmektedir. $\mathrm{Bu}$ çerçevede temel eğitimde ve yaşam boyu eğitim sürecinde yaşantılara dayalı çok yönlü öğrenme ve yaşam alanları olarak müzelerin etkin kullanımını içeren müze pedagojisi ortaya çıkmıştır." Alan yazını incelendiğinde müze eğitimine karşılık gelen, müze pedagojisi, müze eğitbilimi ve müze eğitimbilimi gibi adlandırmaların da kullanıldığı görülmektedir.).

Onur'a $(2012,189)$ göre, "müze eğitimi kimileri için müzenin bir bütün olarak amacinı tanımlar, kimileri için de uzman müze personelinin çalışmaları anlamına gelir." "Müze pedagojisi, insanlararası iletişim ve etkileşimi geliştirici bir alan olarak, müze ve galerilerin her yaş insan için ideal bir öğrenme ortamı olmasını amaçlamaktadır” (Paykoç ve Baykal, 2000; 103).

Müze eğitimi, ziyaretçilerin, müzede sergilenen nesne, değer ve bilgileri etkin bir biçimde öğrenebilmelerini sağlayacak eğitimin ilke, yöntem ve uygulamaları üzerine çalışan bir bilim dalıdır. Müze eğitimi, müze ve sergilenen konularla ilgili herhangi bir broşürün hazırlanmasından eğitim programlarının hazırlanmasına, (eğitim amaçlı) ortamın düzenlenmesinden ziyaretçilere yapılacak olan danışmanlığa kadar müzelerde gerçekleştirilecek olan eğitim etkinliklerini planlar, uygular ve değerlendirir (Beştepe, 1995). 


\section{Müze Eğitimi ve Uygulamaları Dersi}

Müze eğitimi, Müze Eğitimi ve Uygulamaları dersi ile eğitim fakültelerinin yeniden yapılandırılması sürecinde 1998 yılında Resim İş Eğitimi Programına girmiştir. Yedinci dönemde yer alan Müze Eğitimi ve Uygulamaları dersi iki teorik, iki uygulama olmak üzere dört saatlik bir derstir. 2007 yılında Yüksek Öğretim Kurulu tarafından yayımlanan Eğitim Fakültesi Öğretmen Yetiştirme Lisans Programları'nda (http://www.yok.gov.tr/documents, 2017) Müze Eğitimi ve Uygulamaları dersinin içeriği "müzeciliğin tarihi, çeşitleri, amaçları, gerekliliği, müze ve eğitim, eğitim amaçlı müze ziyareti, ilköğretim/ortaöğretim öğrencileri için müze rehberi hazırlama ve uygulama, müze ziyareti için ön hazırlık, plan ve kurallar, müzenin tanımı, sergileme, müzedeki eserlerin tarihsel, estetik ve eleştirel incelenmesi, müzedeki eser ve kalıntılardan yararlanarak yapılan uygulama çalışmaları" şeklindedir.

Bu içerik temel alınarak, Müze Eğitimi ve Uygulamaları dersinin amacı genel olarak, müzeye ilişkin temel kavramları, tarihini, türlerini, amacı ve işlevlerini ve gerekliliğini; müzenin kültür, sanat, eğitim ve toplum ile ilişkisini; sanat eğitiminde müzelerden etkin bir şekilde yararlanabilme yollarını kavratmak şeklinde belirlenebilir. Burada belirtilmesi gereken bir nokta bulunmaktadır. Müze Eğitimi ve Uygulamaları dersi, müze eğitiminde olduğu gibi sanat galerilerini de kapsar. Resim İş Öğretmenliği Programı açısından düşünüldüğünde sanat galerileri müze eğitimi kapsamında önemli bir yer tutar.

Buraya kadar belirtilenler 1şığında, müzelerin günümüzde hem birey hem de toplumsal açıdan önemi ile dersin içeriği ve amacı göz önüne alındığında, Müze Eğitimi ve Uygulamaları dersinin bazı işlevleri öne çıkıyor. Bu işlevler gerçekleşirken ilk anda ilgili program öğrencileri etkilenirken, sonrasında bu öğrencilerin öğretmenliğe başlamalarıyla birlikte onların öğrencilerinin de etkileneceği düşünülebilir. Dolayısıyla bu dersin işlevleri sadece ders ile ve bu dersi alan öğrencilerle sınırlı kalmayıp, değişik eğitim kademelerindeki öğrencilere ve hatta bu öğrencilerin ailelerine kadar yansıyacağ1 söylenebilir.

$\mathrm{Bu}$ işlevlerden ilki, görsel sanatlar öğretmeni adaylarına, yüzyıllar boyunca insanlığın ürettiğ kültürel, sanatsal, bilimsel ve teknolojik birikimi yine insanlara sunan müzelerden etkili yararlanma yollarını göstermektir. Bu öğretmen adaylarının ileride öğrencilerinin dolayısıyla toplumun müze gezmelerine; müzelerde sunulanlar aracılığıyla bilgi ve görgülerini artırmalarına ve müzelerden etkili yararlanmalarını sağlama konusunda önemli bir rol üstlenebilecekleri düşünülürse dersin önemli bir işlevinin ortaya çıktığı görülür. Icom'a (akt. Akmehmet, 2012; 195-196) göre, "çağdaş müzecilikte müzeler artık sadece koleksiyonları ile var olan, onları koruyan, araştıran ve sergileyen kurumlar değillerdir. Müzeler aynı zamanda eğitim etkinlikleriyle de var olmakta; koleksiyonları aracılığıyla toplumdaki farklı izleyici gruplarıyla iletişim kurmak ve müzenin öğrenme potansiyelini yükselterek izleyicilerinin gelişimlerine katkıda bulunmak müzelerin temel sorumlulukları arasında kabul edilmektedir." Ziyaretçilere, müzelerin koleksiyonları herhangi bir ek etkinlik olmadan da bir şeyler öğretebilir. Ancak müzelerin bir eğitim ortamı, bir öğrenme alanı olarak değerlendirilmesiyle birlikte, çeşitli program ve etkinlik çerçevesinde gerçekleştirilen müze ziyaretlerinde müzelerin çok daha etkili bir bilgi kaynağı olduğu ve ziyaretçi açısından da daha çok öğrenmenin gerçekleşeceği açıktır. Bu çerçevede müzeler eğitim sorumlulukları kapsamında çeşitli etkinlikleri yürütürken, gelen ziyaretçilerin müzelerden daha etkili yararlanma yolları konusunda bilinçli olmaları gerçekleşecek eğitimin ve öğrenmenin niteliğini etkileyecektir. Bu noktada devreye girebilecek faktörlerden birisi 
de yukarıda belirtilen ve müzelerden yararlanma yolları konusunda bilgisi olduğu düşünülen görsel sanatlar öğretmenleridir. Hem meslekleri hem de özelde aldıkları müze eğitimi ve uygulamaları dersi açından, görsel sanatlar öğretmenlerinin öğrencilerine, öğrencileri aracılı̆̆ıyla ailelerine ve dolaylı olarak topluma müzelerden bilgi edinme konusunda katkı sağlayacakları düşünülebilir.

Müze eğitimi ve uygulamaları dersinin bir diğer işlevi ise, dersi alan öğrencilerde bir müze bilinci oluşumuna katkı sağlamasıdır. TDK Türkçe Sözlükte bilinç (www.tdk.gov.tr, 2017), "İnsanın kendisini ve çevresini tanıma yeteneği; temel bilgi, temel görüş; algı ve bilgilerin zihinde duru ve aydınlık olarak izlenme süreci” şeklinde açıklanmıştır. Müze bilinci de, müzenin ve müze ile ilgili temel kavramların bilinmesi, müzenin sadece çeşitli nesnelerin sergilendiği kurumlar olmadığı, bu sergilenenler yani koleksiyonlarıyla yüzyılların kültürel üretimini barındırdıklarının, önemli bir öğrenme ortamı olduğunun farkında olunması şeklinde açıklanabilir. Müzelerin birinci elden öğrenme olanağı sunan kurumlar olduklarının bilinmesi gerekir. Müzelerle ilgi kurmanın, bir bilinç, kültür ve görgü gerektirdiği düşünülebilir. Müzelerin koleksiyonları üzerinden bilgi edinme, geçmiş ile bugün arasında bağ kurma, karşılaştırma yapma vb. şeyler bireyde bir ilgi durumunu gerektirir. Müze Eğitimi ve Uygulamaları Dersi, görsel sanatlar öğretmeni adayında bu ilgiyi oluşturma, dolayısıyla müze bilincini geliştirme açısından da bir işleve sahiptir.

Müze Eğitimi ve Uygulamaları dersinin bir diğer işlevi de yine müzelerin eğitim olanaklarından kaynaklanır. Buraya kadar zaman zaman değinilen, müzelerde, yüzyılların kültürel birikiminin örneklerinin bulunması, çeşitli alanlarla ilgili birinci el örneklerin ve bilgilerin bulunması; bu sunulanların öğrenilmesi noktasında da ziyaretçilerin fiziksel ve zihinsel olarak sürece katılmaları müzelerin eğitim olanaklarındandır. Müzeler, her kademe eğitim-öğretim programlarında yer alan pek çok dersi koleksiyonlarıyla destekler niteliktedir. Rose’a göre, “okul dersleri arasında, müzelerde var olan malzemeden, doğru olarak kullanıldığı takdirde, daha canlı bir hale getirilemeyecek olanı yoktur. Edebiyatın dayandığg koşullar, gerek teknik gerekse doğa bilimleri, tarih, coğrafya, sanat, mimari, süsleme ve mesleki konular hep okul programlarında yer alıp müzelerde takviye edilebilecek birçok dersten birkaçıdır” (Rose, 1958; Beştepe, 1995; 31). Sanat eğitimi kapsamında bakıldığında müzeler hem genel kültür hem de sanat dallarına ilişkin örnekleri barındırırlar. Sanat eğitimi açısından sanat galerileri de müzelerle birlikte ele alınmalıdır. Öğretmen adaylarının birinci el sanat eseri örnekleriyle ya da çeşitli nesnelerle çalışmaya, o eserlerden kopya çalışmaları yapmalarına, onları çözümlemelerine ve öğretmen adaylarının kendi çalışmalarıyla ilişkilendirerek kendi sanat anlayışlarının geliştirmelerine müzeler ve sanat galerileri ortam sağlarlar. Kuşkusuz bunlar sadece Müze Eğitimi ve Uygulamaları Dersi kapsamında gerçekleştirilmemektedir. Bu ders, öğretmen adaylarına, müze ve galerilerin bu olanaklarını ve bu olanaklardan hangi amaçla, nasıl, ne zaman gibi yönlerden yararlanabilecekleri yolları gösterir. Müze Eğitimi ve Uygulamaları dersi ve yürüten öğretim elemanları, Resim İş Eğitimi Programında yer alan, desen, temel tasarım, anasanat atölye, seçmeli sanat atölye, sanat tarihi, sanat eleştirisi gibi dersler ve bu derslerin öğretim elemanlarıyla işbirliği yaparak müze ve galeriden etkin yararlanmalarını desteklemelidirler.

Müze Eğitimi ve Uygulama dersinin işlevlerinden bir tanesinin de, kültür ve sanat kurumlarına, mekanlarına gitme alışkanlığının temelinin atılması, bu mekanlara gitmenin önemi ve özellikle bu mekanlara karşı olası çekingenliği ortadan kaldırılmaya çalışıısısı söylenebilir. Öğretmen adayları, yetiştiği kentte yeterli kültür ve sanat kurumunun bulunmaması (bazıları için), içinde bulunduğu sosyo-kültürel ortamın etkisi ya da kendisinin ilgi duymaması nedeniyle üniversiteye gelmeden önce yeterli düzeyde bu kurumlardan yararlanmamış olabilir. Öğretmen adayı üniversiteye gelmeden önce, 
kültür ve sanat kurumlarına ilgi göstermiş ve o mekanlara gitmiş, ama, buradan etkili yararlanma yollarını bilmiyor da olabilir. Bu dersin, öğretmen adaylarına, müzeler ve galeriler aracılığıyla, kültür ve sanat kurumlarının önemi, bu kurumlardan yararlanma yollarını öğrenme ve bu kurumlara gitme alışkanlığı kazandırma bakımından da temel bir işlevi gerçekleştirdiği söylenebilir. Sanatla bağ kurmanın temel yollarından birinin sanat eserleriyle karşılaşma olduğu düşünülürse, bu eserlerin sergilendiği mekanlara gitmenin önemi de ortaya çıkar. Bu nedenle, öğretmen adayları aldıkları bu eğitimle, öğrencilerini hangi eğitim-öğretim kademesinde olurlarsa olsun, olabildiğince en erken yaşlarda müze ve galerilere götürmeliler; kültür ve sanat mekanlarına alışmalarını sağlamalıdırlar.

Müze Eğitimi ve Uygulamaları dersinin bir diğer işlevi de sanat izleyicisinin niteliğini geliştirmedeki katkısı olarak düşünülebilir. Sanat eğitimi genel anlamda "güzel sanatların tüm alanlarını ve biçimlerini içine alan, okul içi ve okul dışı yaratıcı sanatsal eğitimi tanımlamaktadır." (San, 1983; 19). Yine San'a (1983, 20) göre, "günümüzde anlaşıldığ1 biçimiyle genel eğitim süreci içindeki sanat eğitiminin konuları içine, geçmiş ve şimdiki zaman girmekte, kuram ve uygulama ile üretici ve tüketici (izleyiciye düşen) süreçler hep bir arada yer almaktadır.” İster sanatçı adayı, sanat öğretmeni adayı yetiştiren eğitim olsun isterse genel eğitim dizgesi içinde yer alan herkese yönelik verilen sanat eğitimine ilişkin eğitim, kuram ve uygulamayı içerirken; bu süreçlerdeki herkes de üreten ve izleyen konumundadırlar. Sanatçı adayı ya da sanat öğretmeni yetiştiren programlardaki öğrenciler bir yandan sanatsal üretim içindeyken, diğer yandan başka sanatçılar tarafından yaratılan eserleri izlemekte, yani tüketici konumundalardır. Bu durum genel eğitim dizgesinin herhangi bir kademesinde eğitimi-öğretim gören öğrenciler içinde geçerlidir. Sanat derslerinde çeşitli uygulamalar yaparken, diğer taraftan da sanat eserlerini incelerler. Sanatla ilgili tüm eğitim süreçlerinde, sanat ve sanat dallarıyla bağ kuran, sanatı ve eserlerini anlamaya çalışan, sanata yaşamında yer açan ve yaşamının kaliteli olması için sanatın gerekliliğinin farkında olan bireyler yetiştirmek temel noktadır. Bu sanat eğitimi ile ilgili süreçlerde izleyici (kimi sanat dallarında okuyucu, kimisinde dinleyici vb. olabilir) ile sanat eseri arasında kurulan ilişki sanatsal öğrenme ve deneyim için temel gerekliliklerdendir. Sanat eğitimi ve öğretiminde birey ne kadar çok sanat eseriyle karşılaşırsa o kadar öğrenmesi güçlenir; sanat eserleriyle ilişkisi sonucunda estetik deneyimi arttığından estetik beğenisi daha rafine olur. Bireyin, sanat eserleri aracılığıla gerçekleşen olabilirlikleri görme, sorgulama, değerlendirme ve öğrenme ile birlikte sanat görgüsünün ve sanat anlayışının da geliştiği söylenebilir. Erinç $(2004,31)$ "sanatsal bilginin, ancak sanat eseri ile kurulacak teke tek ve dolaysız ilişki sonunda elde edilebileceğini” vurgular. Yani Erinç’e göre bu ilişki dolaysız, aracısız olmalıdır. İzleyici sanat eseri ile teke tek kurduğu ilişki sonucunda estetik deneyimi yaşar ve eserin varlık alanına katılmış olur. Burada aracısız olmaktan, orijinal, birinci el eser kastedilmektedir. Yani, bir resmin, bir heykelin vb. eserlerin herhangi bir kopyası değil kendisinin; bir müzik eserinin konser salonundaki yorumu; bir tiyatro eserinin sahnede izlenmesidir. Kuşkusuz her eserin orijinaline ulaşmak güç olup, böyle bir durumda bir internet sitesindeki, bir kitaptaki ya da bir katalogdaki en yakın kopyasına başvurulabilir; ancak, en iyi kopyada bile renklerde bir değer kaybı yaşanabileceği de bilinir. Buraya kadar yapılan açıklamalar müzelerin, galerilerin ve çeşitli sergilerin izleyici ile senet eserini bir araya getiren, onları karşılaştıran mekanlar olduklarını gösteriyor. Erinç'in belirttiği dolaysız, teke tek ilişki müzeler, galeriler ve sergiler aracılığı ile gerçekleşebilir. Müze Eğitimi ve Uygulamaları Dersi, müzelerdeki, galerilerdeki sanat eserlerine ulaşma konusunda rehberlik ederek, bir farkındalık yaratarak, sanat müzelerinden, sanat galerilerinden yararlanma yollarını göstererek öğretmen adaylarının eğitimlerine katkıda bulunur ve böylelikle önemli bir işlevi daha gerçekleştirir. 


\section{Sonuç}

Son yıllarda kültür, sanat, bilim ve teknolojideki ilerlemelerin müzeleri de etkilediği görülür. Müzelerin tüm işlevlerinin yanı sıra eğitim işlevinin son yıllarda daha da öne çıktığı açıktır. Bireyin değişen eğitim gereksinimleri eğitim dizgelerinde değişikliğe neden olurken, bilgiye ulaşmada hemen her ortamdan doğru bir biçimde yararlanılma yollarının araştırıldığı izlenir. Bireyin eğitim gereksinimi müzelerin eğitim rolünü de etkilemiş ve müzeler yaşayarak, deneyerek öğrenilen; ziyaretçinin aktif olduğu bir öğrenme alanına dönüşmüştür. Müzelerin eğitim öğretim olanaklarının verimliliğinin artırılmasında hem eğitim dizgesine hem de müzelere görev düşmektedir.

Bu bağlamda, Müze Eğitimi ve Uygulamaları dersi, Resim İş Öğretmenliği Lisans Programı çerçevesinde, ilgili bölüm öğrencilerine müzelerin koleksiyonlarından, eğitim olanaklarından yararlanma ve bunları etkin kullanma bakımından yollarını gösterir. Bu çalışmada elde edilen bulgulardan hareketle, Müze Eğitimi ve Uygulamaları dersinin, aşağıda belirtilen işlevleri gerçekleştirdiği sonucuna varılmıştır.

Yüzy1llar boyunca insanlığın ürettiği kültürel, sanatsal, bilimsel ve teknolojik birikimi yine insanlara sunan müzelerden etkili yararlanma yollarını göstermektir.

Müzelere karşı ilgi uyandırarak bir müze bilinci oluşturmak.

Eğitim programlarında yer alan pek çok dersin içeriğine müzeler koleksiyonlarındaki birinci el bilgilerle destek; eğlenceli ve etkin katılımlı bir öğrenme ortamı sunar. Dolayısıyla görsel sanatlar öğretimi kapsamında anasanat atölye, desen, temel tasarım, estetik, sanat tarihi, sanat eleştirisi gibi derslere de sanat eserleri aracılığıyla öğrenme ortamı sağlar. Sanata ilişkin konuların müze ve galerilerle işbirliği halinde işlenmesini desteklemek ve bunun yollarını göstermek.

Sanat eğitimi bağlamında izleyici ile orijinal sanat eserlerinin bir araya gelebildiği ve izleyicinin doğrudan eserle bağ kurabildiği müze, galeri ve sergilerin bu açıdan önemini göstermek.

Müze Eğitimi ve Uygulamaları dersi kapsamında yapılacak müze ve galeri ziyaretleriyle, kültür ve sanat mekanlarına karşı ilgi uyandırmak, alışkanlık geliştirmek ve varsa çekingenlikleri gidermek.

\section{Öneriler}

Yukarıdaki sonuçtan hareketle geliştirilen öneriler şunlardır:

1. Resim İş Öğretmenliği Lisans Programı içinde yer alan anasanat atölye, desen, temel tasarım, sanat eleştirisi, estetik gibi dersler ile müze eğitimi ve uygulamaları dersi arasında bir ilişki kurulması ve öğretim elemanları arasında bir koordinasyonun sağlanması önerilmektedir.

2. Müze Eğitimi ve Uygulamaları dersi sadece Resim İş Öğretmenliği Programında değil, aynı zamanda diğer öğretmen yetiştirme programlarında da yer almalıdır. 


\section{Kaynakça}

Akmehmet Tezcan, K. (2012). Müze eğitimi: okul programları. N. Ertürk ve H. Uralman (Yay. Haz.). Müzeciliğin $\mathrm{ABC}$ 'si içinde. İstanbul: Ege Yayınları.

Atagök, T. (2006). Müze eğitimbilimi ve sanatlar. İ. San ve A. Çakır İlhan (Yay. Haz.). Sanat Eğitiminde Sanat Biliminin Rolü içinde (ss. 59-72). Ankara: Natürel Yayınları.

Batur, S. (1983). Dünyada müzeciliğin gelişsimi. Cumhuriyet Dönemi Türkiye Ansiklopedisi. Cilt 6. Ankara: İletişim Yayınları.

Beştepe, N. E. (1995). Müze eğitbilimi (pedagojisi) ve Türkiye'deki arkeoloji müzelerinin eğitim ortamı olarak etkililiğinin değerlendirilmesi. Yayımlanmamış yüksek lisans tezi, Ankara Üniversitesi Sosyal Bilimler Enstitüsü, Ankara.

Erinç, S. M. (2004). Resmin eleştirisi üzerine. Ankara: Ütopya Yayınları.

Erkanal, H. (1983). Müze ve ziyaretçi. Yeni Adam Aylık Kültür ve Sanat Dergisi, s.23.

Onur, B. (2012). Çağdaş müze eğitim ve gelişim müze psikolojisine giriş. Ankara: İmge Kitabevi.

Paykoç, F. ve Baykal, S. (2000). Müze pedagojisi: kültür, iletişim ve aktif öğrenme ortamı olarak müzelerin etkinliğine iliş̧kin bir çalışma. Z.A. Kızılyaprak (Yay. Haz.). Müzecilikte Yeni Yaklaşımlar Küreselleşme ve Yerelleşme içinde (ss.102-113). İstanbul: Türkiye Ekonomik ve Toplumsal Tarih Vakfı Yayınları.

Riviere, G.H., (1962). Müzelerin eğitimdeki rolü hakkında UNESCO bölge semineri (Çev. Selma İnal). İstanbul: ICOM Türkiye Milli Komitesi Yayınları.

San, İ. (1983). Sanat eğitimi kuramları. Ankara: Tan Yayınları.

TDK. (2017). Büyük Türkçe Sözlük. Bilinç başlı̆ı. TDK web sitesinden 06 Kasım 2017 tarihinde erişildi:http://www.tdk.gov.tr/index.php?option=com_bts\&arama=kelime\&guid=TDK.GTS.5a2c2daa$18 \mathrm{~d} 1 \mathrm{e} 4.03967719$.

YÖK. (2007). Eğitim Fakültesi Öğretmen Yetiştirme Lisans Programları. Yüksek Öğretim Kurulu web sitesinden 08 Kasım 2017 tarihinde erişildi: http://www.yok.gov.tr/documents/10279/30217/EĞİTIM+FAKÜLTESI\%\%20ÖĞRETMEN+YETIŞYETIŞ+LİSANS+PROGRAMLARI.pdf/054dfc9e-a753-42e6-a8ad$674180 \mathrm{~d} 6 \mathrm{e} 382$. 
